\title{
Front Matter: Volume 7455
}

, "Front Matter: Volume 7455," Proc. SPIE 7455, Satellite Data Compression, 'Communication, and Processing V, 745501 (4 September 2009); doi:

10.1117/12.844706

SPIE Event: SPIE Optical Engineering + Applications, 2009, San Diego, California, SPIE. United States 


\section{PROCEEDINGS OF SPIE}

\section{Satellite Data Compression, Communication, and Processing $V$}

Bormin Huang

Antonio J. Plaza

Raffaele Vitulli

Editors

4-5 August 2009

San Diego, California, United States

Sponsored and Published by

SPIE

Volume 7455

Proceedings of SPIE, 0277-786X, v. 7455 
The papers included in this volume were part of the technical conference cited on the cover and title page. Papers were selected and subject to review by the editors and conference program committee. Some conference presentations may not be available for publication. The papers published in these proceedings reflect the work and thoughts of the authors and are published herein as submitted. The publisher is not responsible for the validity of the information or for any outcomes resulting from reliance thereon.

Please use the following format to cite material from this book:

Author(s), "Title of Paper," in Satellite Data Compression, Communication, and Processing V, edited by Bormin Huang, Antonio J. Plaza, Raffaele Vitulli, Proceedings of SPIE Vol. 7455 (SPIE, Bellingham, WA, 2009) Article CID Number.

ISSN 0277-786X

ISBN 9780819477453

Published by

SPIE

P.O. Box 10, Bellingham, Washington 98227-0010 USA

Telephone +1 3606763290 (Pacific Time) · Fax +1 3606471445

SPIE.org

Copyright (C) 2009, Society of Photo-Optical Instrumentation Engineers

Copying of material in this book for internal or personal use, or for the internal or personal use of specific clients, beyond the fair use provisions granted by the U.S. Copyright Law is authorized by SPIE subject to payment of copying fees. The Transactional Reporting Service base fee for this volume is $\$ 18.00$ per article (or portion thereof), which should be paid directly to the Copyright Clearance Center (CCC), 222 Rosewood Drive, Danvers, MA 01923. Payment may also be made electronically through CCC Online at copyright.com. Other copying for republication, resale, advertising or promotion, or any form of systematic or multiple reproduction of any material in this book is prohibited except with permission in writing from the publisher. The CCC fee code is 0277-786X/09/\$18.00.

Printed in the United States of America.

Publication of record for individual papers is online in the SPIE Digital Library.

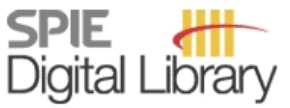

SPIEDigitalLibrary.org

Paper Numbering: Proceedings of SPIE follow an e-First publication model, with papers published first online and then in print and on CD-ROM. Papers are published as they are submitted and meet publication criteria. A unique, consistent, permanent citation identifier (CID) number is assigned to each article at the time of the first publication. Utilization of CIDs allows articles to be fully citable as soon they are published online, and connects the same identifier to all online, print, and electronic versions of the publication. SPIE uses a six-digit CID article numbering system in which:

- The first four digits correspond to the SPIE volume number.

- The last two digits indicate publication order within the volume using a Base 36 numbering system employing both numerals and letters. These two-number sets start with 00, 01, 02, 03, 04, $05,06,07,08,09,0 \mathrm{~A}, 0 \mathrm{~B} \ldots \mathrm{OZ}$, followed by 10-1Z, 20-2Z, etc.

The CID number appears on each page of the manuscript. The complete citation is used on the first page, and an abbreviated version on subsequent pages. Numbers in the index correspond to the last two digits of the six-digit CID number. 


\section{Contents}

vii Conference Committee

\section{SESSION 1 SATELLITE DATA COMPRESSION I}

745502 Hyperspectral information compression (Invited Paper) [7455-01]

C.-I. Chang, Univ. of Maryland, Baltimore County (United States)

745503 Multicomponent compression with the latest CCSDS recommendation [7455-02]

C. Thiebaut, R. Camarero, CNES (France)

745504 Hyperspectral image lossless compression algorithm based on adaptive band regrouping [7455-03]

M. He, L. Bai, Y. Dai, J. Zhang, Northwestern Polytechnical Univ. (China)

745505 A resilient and quick data compression method of prediction errors for space missions [7455-04]

J. Portell, Univ. de Barcelona (Spain) and Institut d'Estudis Espacials de Catalunya (Spain);

A. G. Villafranca, E. García-Berro, Univ. Politècnica de Catalunya (Spain) and Institut d'Estudis Espacials de Catalunya (Spain)

\section{SESSION 2 SATELLITE DATA PROCESSING I}

745507 Bit allocation for 2D compression of hyperspectral images for classification [7455-06] S. Lee, J. Lee, C. Lee, Yonsei Univ. (Korea, Republic of)

745508 Progressive dimensionality reduction for hyperspectral imagery [7455-07] H. Safavi, K.-H. Liu, C.-I. Chang, Univ. of Maryland, Baltimore County (United States)

7455 OA Impact of JPEG2000 compression on spatial-spectral endmember extraction from hyperspectral data [7455-09]

G. Martín, Univ. of Extremadura (Spain); V. G. Ruiz, Univ. Almería (Spain); A. Plaza, Univ. of Extremadura (Spain); J. P. Ortiz, I. García, Univ. Almería (Spain)

SESSION 3 FPGA- OR GPU-BASED DATA COMPRESSION: JOINT SESSION WITH CONFERENCE 7458

7455 OC GPUs for data parallel spectral image compression [7455-11]

J. Mielikainen, R. Honkanen, P. Toivanen, Univ. of Kuopio (Finland); B. Huang, Univ. of Wisconsin-Madison (United States)

7455 OD Low-cost wavelet image compression for FPGAs [7455-12]

J. R. Hayes, K. Strohbehn, G. A. Murphy, The Johns Hopkins Univ. Applied Physics Lab. (United States) 
7455 OE VLSI architecture of wavelet transform based on basic lifting elements [7455-13]

J. Guo, Y. Li, K. Wang, C. Wu, Xidian Univ. (China)

7455 OF Lossy hyperspectral image compression tuned for spectral mixture analysis applications on NVidia graphics processing units [7455-14]

A. Plaza, J. Plaza, S. Sánchez, A. Paz, Univ. of Extremadura (Spain)

\section{SESSION 4 SATELLITE DATA COMPRESSION II}

7455 Ol Segmented PCA and JPEG2000 for hyperspectral image compression [7455-17]

W. Zhu, Q. Du, J. E. Fowler, Mississippi State Univ. (United States)

7455 0J JPEG2000 rate-control for improved transmission of windows-of-interest in remote sensing scenarios [7455-18]

J. L. Monteagudo-Pereira, J. Bartrina-Rapesta, F. Aulí-Llinàs, J. Serra-Sagristà, Autonomous Univ. of Barcelona (Spain)

7455 OK Hyperspectral image reconstruction based on an improved genetic algorithm [7455-19]

L. Wang, S. Guo, R. Ren, Jilin Univ. (China)

$7455 \mathrm{OL} \quad$ Study of the codeword assignment for a revised Tunstall code [7455-20]

S.-C. Wei, Tamkang Univ. (Taiwan); B. Huang, Univ. of Wisconsin-Madison (United States)

\section{SESSION 5 SATELLITE DATA PROCESSING II}

7455 OM Design and analysis of real-time endmember extraction algorithms for hyperspectral imagery [7455-21]

C.-I. Chang, C.-C. Wu, Univ. of Maryland, Baltimore County (United States)

7455 ON Road extraction in remote sensing images based on PCNN and mathematical morphology [7455-22]

X. Wang, H. Zhao, Z. Tang, G. Fu, Tsinghua Univ. (China)

$745500 \quad$ Massively parallel processing of remotely sensed hyperspectral images [7455-23]

J. Plaza, A. Plaza, D. Valencia, A. Paz, Univ. of Extremadura (Spain)

\section{SESSION 6 SATELLITE DATA COMPRESSION III}

$74550 Q \quad$ Region-based compression of remote sensing stereo image pairs [7455-25]

R. Yan, Y. Li, C. Wu, K. Wang, Xidian Univ. (China); S. Li, Harbin Institute of Technology (China)

7455 OR A lossless compression method based on mix coding and IWT for MODIS image [7455-27]

R. Ren, S. Guo, L. Gu, L. Wang, X. Wang, Jilin Univ. (China)

7455 OT Adaptive GOP structure based on motion coherence [7455-29]

Y. Ma, Xidian Univ. (China); S. Wan, Northwestern Polytechnical Univ. (China); Y. Chang,

F. Yang, Xidian Univ. (China); X. Wang, Air Force Engineering Univ. (China) 
7455 OU Lossy compression of MERIS superspectral images with exogenous quasi optimal coding transforms [7455-30]

I. P. Akam Bita, LUXSPACE Sarl (Luxembourg); M. Barret, SUPELEC (France); F. Dalla Vedova, LUXSPACE Sarl (Luxembourg); J.-L. Gutzwiller, SUPELEC (France)

7455 OV Effects of image compression on the accuracy of the Digital Terrain Model (DTM) derived from satellite images [7455-26]

W. Yu, H. Xin, N. Rui, Y. Zhe, Xi'an Research Institute of Surveying and Mapping (China)

\section{SESSION 7 SATELLITE DATA PROCESSING III}

$7455 \mathrm{OW}$ An ad-hoc approach for quality assessment of hyperspectral datacubes in target detection [7455-31]

R. Rashidi Far, S.-E. Qian, Canadian Space Agency (Canada)

$74550 \mathrm{X}$ Comparative analysis of different implementations of a parallel algorithm for automatic target detection and classification of hyperspectral images [7455-32]

A. Paz, A. Plaza, J. Plaza, Univ. of Extremadura (Spain)

7455 OY Automated display of hyperspectral images with unsupervised segmentation [7455-33]

S. Lee, J. Lee, C. Lee, Yonsei Univ. (Korea, Republic of)

$74550 Z$ An effective method for the detection and removal of thin clouds from MODIS image [7455-34]

R. Ren, S. Guo, L. Gu, L. Wang, X. Wang, Jilin Univ. (China)

745510 A novel adaptive noise filtering method for SAR images [7455-35]

W. Li, Xianyang Normal Univ. (China); M. He, Northwestern Polytechnical Univ. (China)

745511 LDPC-coded signal space diversity with precoding over Rayleigh fading channels [7455-36] Z. Shi, Univ. of Electronic Science and Technology of China (China) and Southeast Univ. (China); J. Hu, Northwestern Polytechnical Univ. (China); Z. Zhang, Univ. of Electronic Science and Technology of China (China)

\section{POSTER SESSION}

745512 Using a weighted zeroblock coder (WZBC) for satellite image compression [7455-37] J. Wu, Y. Xing, L. Jiao, Xidian Univ. (China)

745513 Hyperspectral image compression using distributed source coding with 3D-wavelet and LDPC [7455-38]

J. Wu, K. Jiang, Xidian Univ. (China); Y. Fang, Northwest A\&F Univ. (China); L. Jiao, Xidian Univ. (China)

Author Index 
Downloaded From: https://www.spiedigitallibrary.org/conference-proceedings-of-spie on 26 Apr 2023

Terms of Use: https://www.spiedigitallibrary.org/terms-of-use 


\title{
Conference Committee
}

\author{
Conference Chairs
}

Bormin Huang, University of Wisconsin, Madison (United States)

Antonio J. Plaza, Universidad de Extremadura (Spain)

Raffaele Vitulli, European Space Agency (Netherlands)

\section{Cochairs}

Chulhee Lee, Yonsei University (Korea, Republic of)

Shen-En Qian, Canadian Space Agency (Canada)

Chengke Wu, Xidian University (China)

Program Track Chair

Allen H.-L. Huang, University of Wisconsin, Madison (United States)

\section{Program Committee}

Isidore Paul Akam Bita, LUXSPACE Sarl (Luxembourg)

Chein-I Chang, University of Maryland, Baltimore County (United States)

Qian Du, Mississippi State University (United States)

LingJia Gu, Jilin University (China)

Shuxu Guo, Jilin University (China)

Mingyi He, Northwestern Polytechnical University (China)

Roger W. Heymann, National Oceanic and Atmospheric Administration (United States)

Yu-Hen Hu, University of Wisconsin, Madison (United States)

Matthew A. Klimesh, Jet Propulsion Laboratory (United States)

Weibin Li, Xianyang Normal University (China)

Yunsong Li, Xidian University (China)

Enrico Magli, Politecnico di Torino (Italy)

Jarno S. Mielikainen, University of Kuopio (Finland)

Jordi Portell, Universitat de Barcelona (Spain)

Jeffery J. Puschell, Raytheon Space \& Airborne Systems (United States)

Ana María Clara Ruedin, Universidad de Buenos Aires (Argentina) Joan Serra-Sagristà, Universitat Autònoma de Barcelona (Spain)

Zhiping Shi, University of Electronic Science and Technology of China (China)

Carole Thiebaut, Centre National d'Études Spatiales (France)

Shuai Wan, Northwestern Polytechnical University (China)

Shih-Chieh Wei, Tamkang University (Taiwan) 
Session Chairs

1 Satellite Data Compression I

Bormin Huang, University of Wisconsin, Madison (United States)

2 Satellite Data Processing I

Antonio J. Plaza, Universidad de Extremadura (Spain)

3 FPGA- or GPU-based Data Compression: Joint Session with Conference 7458

Jordi Portell, Universitat de Barcelona (Spain)

Jeffery J. Puschell, Raytheon Space \& Airborne Systems (United States)

3 FPGA- or GPU-based Data Compression: Joint Session with Conference 7458

Jordi Portell, Universitat de Barcelona (Spain)

Jeffery J. Puschell, Raytheon Space \& Airborne Systems (United States)

4 Satellite Data Compression II

Chulhee Lee, Yonsei University (Korea, Republic of)

5 Satellite Data Processing II

Allan Hollinger, Canadian Space Agency (Canada)

$6 \quad$ Satellite Data Compression III

Roberto Camarero, Centre National d'Études Spatiales (France)

7 Satellite Data Processing III

Jarno S. Mielikainen, University of Kuopio (Finland) 